\title{
Pertumbuhan dan Hasil Gandum pada Berbagai Kerapatan Populasi dan Dosis Pemupukan Urea
}

\author{
Growth and Yield of Wheat Varieties at Various Population Densities and Doses of Urea \\ Akhmad Zubaidi*, Dwi Ratna Anugrahwati, dan Uyek Malik Yakop \\ Jurusan Budidaya Pertanian, Fakultas Pertanian, Universitas Mataram \\ Jl. Majapahit 62, Mataram Lombok, 83125, Indonesia
}

Diterima 25 Maret 2018/Disetujui 9 Agustus 2018

\begin{abstract}
Efforts to produce wheat in Indonesia need to be supported by the availability of cultivation technology suitable for agro-climate conditions in Indonesia, including the use of proper population density and fertilization dosages, which are fundamental for obtaining maximum yields. This study was aimed to determine ideal population density and dosage of urea for optimum grain yield of wheat in Lombok Island. The experiment carried out at Aik Bukak, Central Lombok at elevation of $400 \mathrm{~m}$ asl, to observe the growth and yield of two varieties of wheat, Nias and Gladius, with 4 plant population densities (133, 160, 200, and 250 plants $\mathrm{m}^{-2}$ ) and 3 dosages of urea fertilization, 200, 300, and $400 \mathrm{~kg} \mathrm{ha}^{-1}$. Data from this study indicated that Lombok Island has the potential for growing wheat with quite dense population density of 250 plants $\mathrm{m}^{-2}$. This density yielded higher, 1.74 tons $\mathrm{ha}^{-2}$, due to the increased number of kernel per unit area without reducing individual kernel weight. The use of urea $300 \mathrm{~kg} \mathrm{ha}^{-1}$ exhibited the best growth and yielded 1.32 tons ha-2.
\end{abstract}

Keywords: fertilization, population density, wheat varieties

\section{ABSTRAK}

Usaha memproduksi gandum di Indonesia perlu didukung oleh ketersediaan penerapan teknologi budidaya yang sesuai dengan kondisi agroklimat di Indonesia, diantaranya adalah penggunaan kerapatan populasi tanaman dan pemupukan yang tepat, yang merupakan faktor mendasar dalam mendapatkan hasil panen maksimal. Percobaan ini bertujuan untuk mengetahui kerapatan populasi tanaman yang ideal dan dosis pemupukan urea yang tepat bagi produksi maksimum gandum di Pulau Lombok. Percobaan dilakukan di Aik Bukak Lombok Tengah, pada ketinggian tempat $400 \mathrm{~m}$ dpl, dengan metode eksperimental untuk mengamati pertumbuhan dan hasil 2 varietas gandum yaitu Nias dan Gladius, dengan 4 kerapatan populasi tanaman yaitu 133, 160, 200, dan 250 tanaman $\mathrm{m}^{-2}$ serta 3 dosis pemupukan urea: 200, 300, 400 kg ha. . Data penelitian ini menunjukkan bahwa gandum berpotensi untuk ditanam di pulau Lombok dengan populasi yang cukup rapat yaitu. Populasi 250 tanaman per $\mathrm{m}^{2}$ tersebut memberikan hasil panenan yang lebih tinggi, 1.74 ton $\mathrm{m}^{-2}$, karena meningkatnya jumlah biji per satuan luas, tanpa menurunkan bobot per butir biji. Pemberian pupuk $300 \mathrm{~kg} \mathrm{ha}^{-1}$ urea memberikan pertumbuhan yang baik dengan hasil 1.32 ton $\mathrm{ha}^{-2}$.

Kata kunci: kerapatan populasi, pemupukan, varietas gandum

\section{PENDAHULUAN}

Indonesia perlu memproduksi gandum (Triticum aestivum) sendiri untuk mengurangi impor yang semakin meningkat. Upaya budidaya gandum di daerah tropis dapat dilakukan dengan perakitan varietas-varietas baru adaptif daerah tropis (Putri et al., 2013; Febrianto et al., 2015; Wardani et al., 2015) dapat juga dengan upaya adaptasi agro-fisiologis varietas-varietas introduksi, serta pengembangan standar budidaya untuk mencapai hasil yang optimal. Percobaan yang dilakukan di pulau Lombok pada tahun 2010 sampai dengan 2013 menunjukkan bahwa tanaman gandum introduksi dari Australia dan varietas nasional dapat tumbuh dan berproduksi dengan baik serta mempunyai peluang untuk dikembangkan (Zubaidi, 2015).

Pulau Lombok yang terletak pada $8^{\circ} \mathrm{LS} 116^{\circ} \mathrm{BT}$ merupakan wilayah yang cukup potensial untuk pengembangan tanaman gandum jika ditanam pada waktu dan ketinggian tempat yang memadai, mengingat sebaran suhu tahunan sangat dipengaruhi oleh tiupan angin muson.

\footnotetext{
*Penulis untuk korespondensi. e-mail: akhmad.zubaidi@gmail.com
} 
Suhu terendah pulau Lombok terjadi pada bulan-bulan Juli-September sebagai akibat dari tiupan angin muson Timur dari arah Australia, yang bersamaan terjadinya dengan curah hujan terendah (WMO, 2018). Simulasi yang dilakukan oleh Gusmayanti et al. (2006) dan Handoko (2007) menunjukkan bahwa gandum dimungkinkan untuk diproduksi di Pulau Lombok dengan potensi hasil antara 1.5-3.0 ton $\mathrm{ha}^{-1}$. Percobaan adaptasi gandum yang dilakukan di Pulau Lombok menunjukkan bahwa gandum potensial untuk dibudidayakan antara bulan Juni sampai dengan bulan September, pada ketinggian tempat $400 \mathrm{~m}$ dpl atau lebih, dengan hasil mencapai 3 ton $\mathrm{ha}^{-1}$ pada dataran dengan ketinggian 1,000 m dpl (Zubaidi, 2015).

Teknik budidaya yang dilakukan sementara ini mengacu kepada tindakan agronomi yang dilakukan untuk tanaman padi. Dalam upaya adaptasi tanaman gandum ini, maka percobaan teknologi budidaya gandum yang tepatguna merupakan langkah yang harus dilakukan, diantaranya populasi penanaman dan pemupukan yang tepat. Percobaanpercobaan adaptasi gandum di Pulau Lombok sementara ini dilakukan dengan populasi penanaman 133 tanaman $\mathrm{m}^{-2}$ seperti penanaman yang dilakukan di Australia dan pemupukan urea dengan dosis $300 \mathrm{~kg}$ urea ha-1 seperti pemupukan yang dilakukan untuk padi. Penanaman dengan populasi 133 tanaman $\mathrm{m}^{-2}$ di Australia memberikan hasil sekitar 2 ton ha ${ }^{-1}$ (Zubaidi, 2015). Penanaman dengan populasi lebih dari 250 tanaman $\mathrm{m}^{-2}$ merupakan acuan untuk daerah berproduksi tinggi seperti di Eropa dengan hasil mencapai 5 ton ha $^{-1}$ (Spink et al., 2000). Percobaan ini bertujuan untuk mengetahui populasi penanaman dan dosis pemupukan urea yang terbaik bagi hasil gandum yang optimal pada penanaman di Pulau Lombok.

\section{BAHAN DAN METODE}

Percobaan ini dilakukan di Desa Aik Bukak, Lombok Tengah, dengan ketinggian tempat $\pm 400 \mathrm{~m}$ dpl, pada Juni sampai dengan Oktober 2015. Kisaran suhu minimum selama percobaan adalah $19-21{ }^{\circ} \mathrm{C}$, sedangkan suhu maksimum 28.5-30.5 ${ }^{\circ} \mathrm{C}$. Percobaan dilakukan dengan menggunakan rancangan acak kelompok lengkap faktorial. Faktor pertama adalah 2 varietas gandum, yaitu Nias yang merupakan varietas nasional dan Gladius varietas introduksi dari Australia, faktor kedua adalah populasi penanaman, yaitu 133, 160, 200, dan 250 tanaman $\mathrm{m}^{-2}$, sedangkan faktor ketiga pemupukan urea $\left(200,300\right.$, dan $\left.400 \mathrm{~kg} \mathrm{ha}^{-1}\right)$. Setiap kombinasi dilakukan dengan 3 kali ulangan, sehingga didapatkan 72 unit percobaan.

Pengolahan tanah dilakukan dengan cara membajak dan menggaru sebanyak dua kali kemudian diratakan lalu dibuatkan petak-petak percobaan dalam 3 blok ulangan dengan jarak antar blok $50 \mathrm{~cm}$, masing-masing blok terdiri dari 24 petak percobaan, ukuran plot $1.5 \mathrm{~m} \mathrm{x} 4 \mathrm{~m}$ dan jarak antar plot $30 \mathrm{~cm}$. Penanaman dilakukan dengan sistem tugal dan jarak tanam disesuaikan perlakuan; yaitu untuk kerapatan populasi 133 tanaman $\mathrm{m}^{-2}$ jarak tanam $30 \mathrm{~cm}$ x 10 cm dengan 4 biji per lubang tanam; populasi 160 tanaman $\mathrm{m}^{-2}$ jarak tanam $25 \mathrm{~cm} \times 10 \mathrm{~cm}, 4$ biji per lubang tanam; populasi 200 tanaman $\mathrm{m}^{-2}$ jarak tanam $25 \mathrm{~cm}$ x $10 \mathrm{~cm}, 5$ biji per lubang tanam; populasi 250 tanaman $\mathrm{m}^{-2}$ jarak tanam 20 $\mathrm{cm} \times 10 \mathrm{~cm}, 5$ biji per lubang tanam.

Pemberian pupuk urea dilakukan 3 kali masing masing sepertiga dosis perlakuan, yaitu saat tanam, saat tanaman mencapai fase pertumbuhan anakan (Growth Stage/GS 21) dan saat kemunculan bunga atau heading (GS 55). Pemberian pupuk majemuk NPK dilakukan sekali, yaitu pada saat tanam dengan dosis $300 \mathrm{~kg} \mathrm{NPK} \mathrm{ha-1}$.

Pengamatan dilakukan terhadap pertumbuhan dan hasil serta komponen-komponen hasil. Pengamatan pertumbuhan meliputi fase perkembangan (fenologi), dan tinggi tanaman, dilakukan pada 20 tanaman contoh yang ditetapkan secara acak pada setiap plot. Pengamatan fase perkembangan, yang mencakup: pertumbuhan bibit (GS 10), pertumbuhan anakan (GS 20), saat pembentukan primordia bunga dan pemanjangan batang (GS 30), saat bunting/booting (GS 45), kemunculan bunga/heading (GS 59), waktu berbunga/ anthesis (GS 69), perkembangan malai/buah (GS 70, 80, 90) dan saat panen (GS 93), dilakukan secara rutin setiap 2 minggu sekali menggunakan Skala Zadoks (Zadoks et al., 1974).

Pemanenan dilakukan pada saat $80 \%$ dari populasi tanaman mencapai kriteria panen (GS 93), yang ditandai dengan malai telah masak fisiologis, batang dan daun sudah menguning serta gabah sudah berwarna kuning dan keras. Pengukuran hasil dan komponen-komponen hasil dilakukan setelah panen. Pengukuran bobot brangkasan kering, jumlah batang/anakan, jumlah malai, jumlah spikelet per malai, jumlah biji, bobot 1,000 biji, jumlah biji per spikelet, dan indeks panen dilakukan terhadap sampel quadrat. Sampel quadrat diambil dari 2 baris tanaman sepanjang $50 \mathrm{~cm}$, kemudian data dikonversi kedalam satuan $\mathrm{m}^{-2}$ (yaitu $\mathrm{g} \mathrm{m}^{-2}$, jumlah $\mathrm{m}^{-2}$ ). Hasil panen ditimbang dari panen seluruh plot, kemudian dikonversikan ke ton $\mathrm{ha}^{-1}$.

Data dianalisis dengan analisis ragam pada taraf nyata 5\%, menggunakan paket statistic GenStat (VSN International Ltd. United Kingdom). Perbedaan antar ratarata perlakuan diuji dengan Least Significant Difference (LSD) pada taraf nyata $5 \%$, dan hubungan antar variabel diuji dengan korelasi dan regresi linier sederhana.

\section{HASIL DAN PEMBAHASAN}

\section{Pertumbuhan dan Perkembangan Tanaman}

Varietas Nias menunjukkan perkembangan tanaman yang lebih cepat daripada varietas Gladius. Nias mencapai fase pembentukan primordia bunga (GS 30) pada 30 hari setelah tanam, sedangkan Gladius pada umur 35 hari setelah tanam. Umur berbunga (GS 69) Nias juga lebih cepat dari pada Gladius, Nias berbunga sekitar 50 hari setelah tanam dan Gladius pada umur 60 hari setelah tanam (Gambar 1).

Perbedaan kecepatan perkembangan pada varietas Nias dan Gladius tidak tampak pada kepadatan populasi penanaman yang berbeda ataupun pada perlakuan pemupukan tanaman. Tanaman dengan populasi lebih tinggi tidak menyebabkan perbedaan perkembangan 
tanaman. Demikian juga dengan tambahan pemupukan tidak memberikan perkembangan tanaman yang lebih cepat (Gambar 1). Kecepatan perkembangan varietas-varietas gandum (fenologi) dalam percobaan ini lebih ditunjukkan oleh perbedaan genetis daripada perbedaan perlakuan, yaitu bahwa Nias dan Gladius berbeda tetapi perlakuan populasi dan pemupukan tidak menyebabkan perbedaan perkembangan tanaman.

Pertambahan tinggi tanaman juga lebih ditunjukkan oleh perbedaan varietas, Nias lebih tinggi dibanding Gladius. Tidak ada perbedaan tinggi tanaman antar perlakuan kepadatan populasi tanaman maupun dosis pemupukan (Gambar 2).

\section{Hasil dan Komponen Hasil}

Hasil percobaan ini tidak menunjukkan adanya interaksi antar perlakuan sehingga data disajikan pada masing-masing pengaruh perlakuan. Nias dan Gladius memberikan hasil yang tidak berbeda nyata (1.32 ton ha ${ }^{-1}$ vs. 1.22 ton $\mathrm{ha}^{-1}$ ) (Tabel 1). Nias memiliki kelebihan dalam keberhasilan pembuahan daripada Gladius, terlihat pada jumlah biji yang dihasilkan pada setiap spikelet lebih tinggi, 2.2 biji per spikelet, dibandingkan dengan Gladius, 1.9 biji per spikelet. Akan tetapi Nias tidak memiliki potensi jumlah anakan dan jumlah malai per satuan luas seperti Gladius; jumlah anakan dan malai produktif yang lebih tinggi mampu menaikkan hasil Gladius sebanding dengan Nias.

Nias memiliki potensi jumlah spikelet per malai yang lebih banyak dibanding Gladius (Zubaidi, 2015). Tabel 1 menunjukkan bahwa Nias memiliki jumlah spikelet pada setiap malai yang lebih banyak daripada Gladius. Keberhasilan pembuahan pada Nias (ditunjukkan dengan jumlah biji/spikelets) lebih tinggi dibanding Gladius dapat disebabkan adaptasi gandum Nias, pada lingkungan suhu tinggi di daerah tropis lebih baik dibanding Gladius yang diintroduksi dan diadaptasikan dari Australia. Heat stress atau cekaman suhu tinggi pada saat fase generatif dapat menyebabkan kegagalan penyerbukan dan mengurangi pembentukan biji yang pada gilirannya akan mengurangi hasil panen (Wahid et al., 2007), meskipun untuk cekaman suhu tinggi dalam waktu yang singkat (Talukder et al., 2014).

Hasil tertinggi diperoleh dari penanaman dengan populasi 250 tanaman $\mathrm{m}^{-2}$ (yaitu 1.74 ton $\mathrm{ha}^{-1}$ ). Penambahan populasi tanaman tidak menurunkan potensi hasil per tanaman maupun proporsi hasil biji (panenan) dibandingkan dengan hasil biologis tanaman dari varietas gandum yang diteliti. Hal ini ditunjukkan oleh jumlah spikelet per malai, jumlah biji per spikelet dan bobot 1,000 biji, serta indeks panen yang tidak berbeda, sehingga pada populasi tertinggi, dengan jumlah malai $\mathrm{m}^{-2}$ terbanyak, memberikan hasil tertinggi (Tabel 1). Hasil panen yang lebih tinggi pada kerapatan populasi tinggi menunjukkan bahwa penanaman gandum di pulau Lombok masih memungkinkan untuk

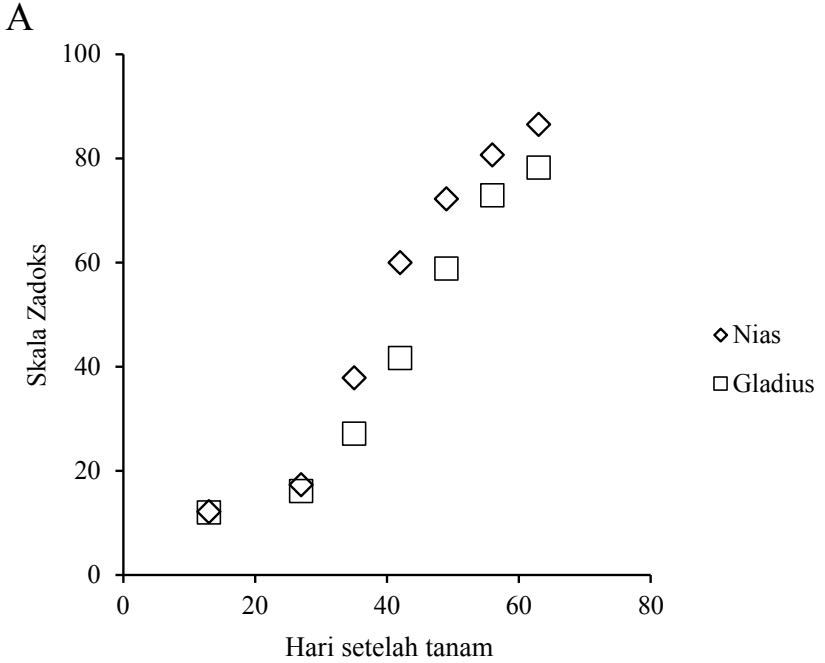

B

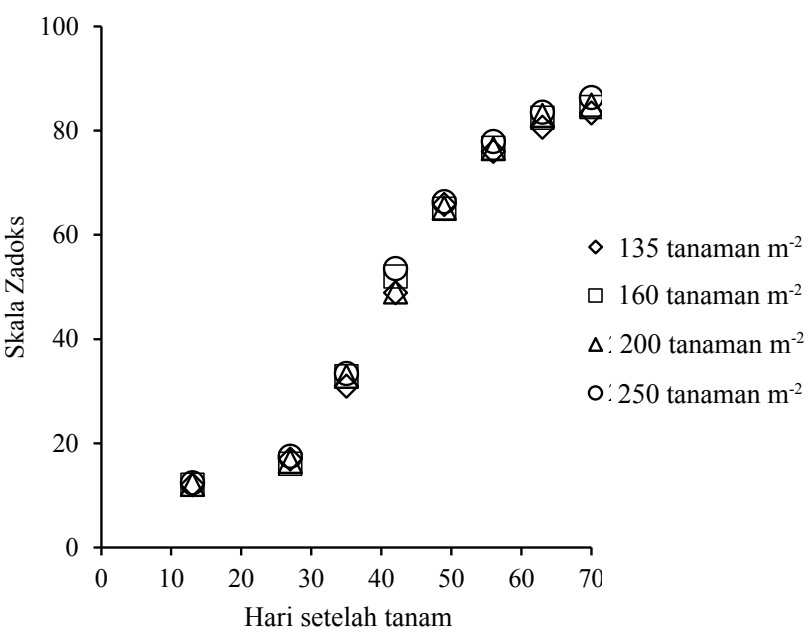

C

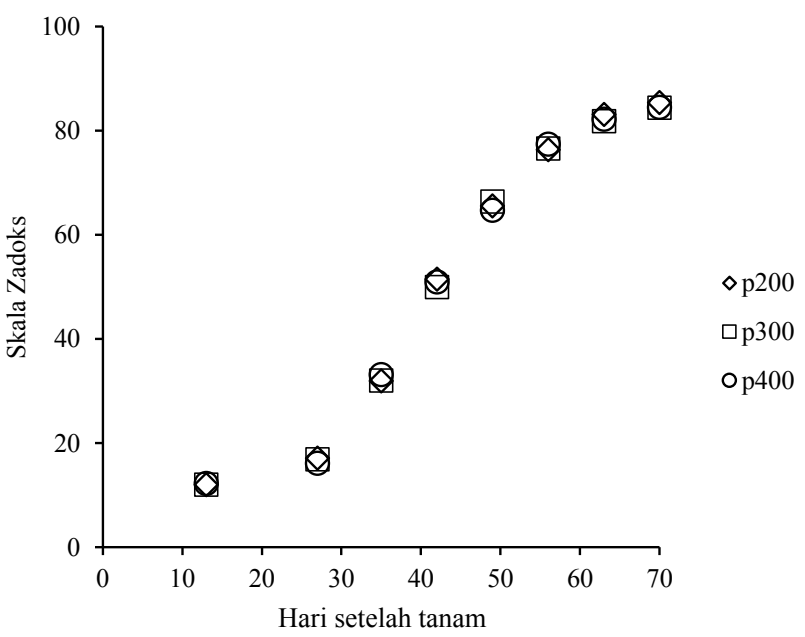

Gambar 1. Perkembangan gandum di lapangan ditunjukkan dengan Skala Zadoks, pada perlakuan varietas (A), kerapatan populasi (B), dan dosis pupuk urea (C). Hasil Analisis Variance menunjukkan perbedaan perkembangan pada varietas yang berbeda, tetapi perlakuan populasi penanaman dan pemupukan tidak berbeda 
dilakukan dengan penambahan populasi tanaman untuk mendapatkan hasil yang lebih tinggi.

Komponen-komponen hasil, seperti jumlah spikelet per malai, jumlah biji per spikelet, bobot 1,000 biji, maupun indeks panen tidak mengalami penurunan (Tabel 1) yang dapat menurunkan hasil, meskipun dengan penanaman
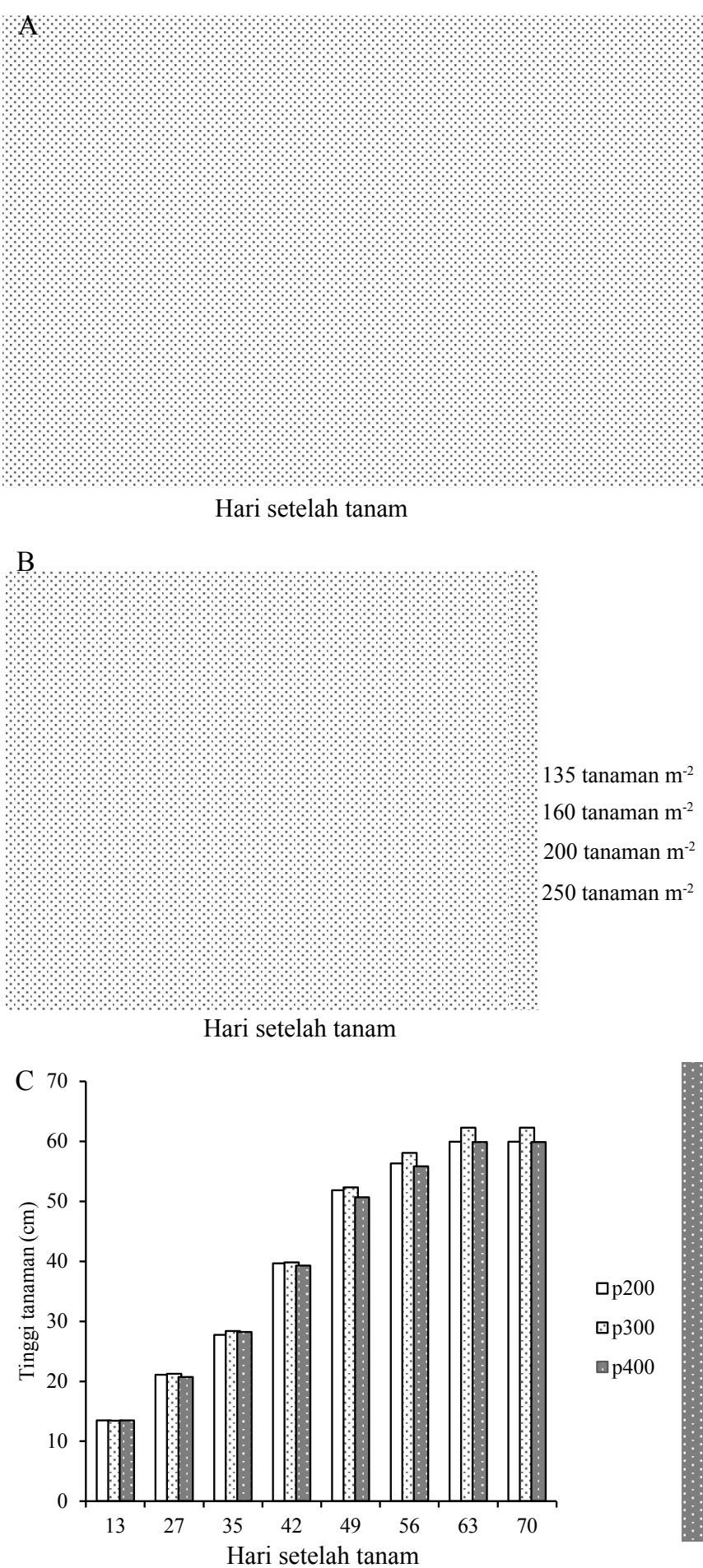

Gambar 2. Tinggi tanaman gandum pada perlakuan varietas (A), kerapatan populasi (B), dan dosis pupuk urea (C). Hasil analisis ragam menunjukkan perbedaan tinggi tanaman pada varietas yang berbeda, tetapi perlakuan populasi penanaman dan pemupukan tidak berbeda populasi tinggi sampai dengan 250 tanaman $\mathrm{m}^{-2}$. Hal serupa ditunjukkan oleh Schillinger dan Wuest (2014) yang menyatakan komponen-komponen hasil tidak dipengaruhi oleh perbedaan jarak barisan tanaman. Berbeda dengan hasil percobaan yang dilakukan Nakano dan Morita (2009) yang menunjukkan penanaman dengan populasi lebih tinggi memilikijumlah malai per $\mathrm{m}^{2}$ lebih tinggitetapimenyebabkan pengurangan jumlah biji per malai yang mengakibatkan penanaman dengan populasi lebih tinggi tidak memberikan hasil yang lebih tinggi. Demikian juga Baloch et al. (2010) melaporkan penambahan populasi memberikan hasil yang lebih tinggi sampai tingkat tertentu, tetapi kemudian tidak memberikan tambahan hasil. Percobaan Baloch et al. (2010) tersebut menunjukkan bahwa populasi penanaman telah mencapai jumlah tertinggi yang dapat didukung oleh lingkungan setempat.

Perlakuan pemupukan dengan dosis rendah, $200 \mathrm{~kg}$ urea $\mathrm{ha}^{-1}$ tidak dapat memberikan hasil yang memadai, sedangkan pemberian pupuk urea dengan dosis tinggi, $400 \mathrm{~kg}$ urea ha $\mathrm{h}^{-1}$, tidak memberikan hasil yang lebih baik dibanding hasil dengan pemberian pemupukan $300 \mathrm{~kg}$ urea ha- ${ }^{-1}$. Pemupukan $300 \mathrm{~kg}$ urea ha-1 merupakan anjuran pemberian pupuk pada tanaman padi yang dilakukan petani di Lombok, yang sementara ini dipergunakan sebagai dosis pemupukan gandum di Lombok. Laporan pemberian pupuk urea bagi tanaman gandum bervariasi tergantung tingkat kesuburan tanah dan faktor-faktor agronomis lainnya. Mandic et al. (2015) melaporkan hasil terbaik diberikan oleh gandum di Chilie yang diberikan pupuk $170 \mathrm{~kg}$ urea $\mathrm{ha}^{-1}$ dengan pemberian pengairan. Sementara Laghari et al. (2010) di Pakistan melaporkan hasil terbaik diperoleh dengan pemupukan $200 \mathrm{~kg}$ urea ha ${ }^{-1}$ yang diikuti dengan pemupukan phosphat dan kalium. Kebutuhan pupuk lebih tinggi yaitu sebanyak $400 \mathrm{~kg}$ urea $\mathrm{ha}^{-1}$, dilaporkan oleh Ali et al. (2011).

Hasil pengujian dengan korelasi dan regresi linier sederhana, menunjukkan bahwa hasil panenan yang diperoleh pada percobaan ini secara nyata dipengaruhi oleh bobot brangkasan kering $(\mathrm{r}=0.95)$, jumlah batang $\mathrm{m}^{-2}$ $(\mathrm{r}=0.92)$, jumlah malai $\mathrm{m}^{-2}(\mathrm{r}=0.93)$ dan jumlah biji $\mathrm{m}^{-2}$ $(\mathrm{r}=0.98)$ (Gambar 3). Bobot brangkasan kering yang lebih tinggi dapat menaikkan hasil akhir karena sesungguhnya hasil biji merupakan fraksi dari bobot kering tanaman yang diakumulasi selama proses pertumbuhan tanaman (Araus et al., 2008; Parry et al., 2011). Akumulasi biomassa selama pertumbuhan tanaman tersebut berkontribusi sangat besar terhadap hasil biji dengan partisi sejumlah besar karbohidrat terlarut (water soluble carbohydate/WSC) sebelumnya tersimpan dalam batang (Shearman et al., 2005).

Dua komponen hasil utama yang berpengaruh terhadap hasil adalah jumlah biji per satuan luas area dan bobot 1,000 biji. Jumlah biji per satuan luas area pada percobaan ini, lebih berpengaruh daripada bobot 1,000 biji. Hal ini banyak terjadi pada percobaan-percobaan peningkatan hasil pada kondisi stress yang dijumpai dipengaruhi oleh jumlah biji per unit area meskipun tanpa atau hanya sedikit dengan peningkatan pada bobot invidual biji (Reynolds et al., 2009; Faulkes et al., 2011; Talukder et al., 2014). 
Tabel 1. Keragaan hasil dan komponen hasil varietas gandum pada populasi dan pemupukan urea yang berbeda

\begin{tabular}{|c|c|c|c|c|c|c|c|c|c|}
\hline Perlakuan & $\begin{array}{c}\mathrm{BBK} \\
\left(\mathrm{g} \mathrm{m}^{-2}\right)\end{array}$ & $\begin{array}{c}\text { Jumlah } \\
\text { batang } \\
\mathrm{m}^{-2}\end{array}$ & $\begin{array}{l}\text { Jumlah } \\
\text { malai m-2 }\end{array}$ & $\begin{array}{c}\text { Jumlah } \\
\text { spi per } \\
\text { malai }\end{array}$ & $\begin{array}{l}\text { Jumlah } \\
\text { biji m-2 }\end{array}$ & $\begin{array}{c}\text { Jumlah } \\
\text { biji per } \\
\text { spi }\end{array}$ & $\begin{array}{l}\text { B1000 } \\
\text { (g) }\end{array}$ & $\begin{array}{c}\text { IP } \\
(\%)\end{array}$ & $\begin{array}{c}\text { Hasil } \\
\left(\text { ton } \mathrm{ha}^{-1}\right)\end{array}$ \\
\hline \multicolumn{10}{|l|}{ Varietas } \\
\hline Gladius & 466.1 & $354.0 \mathrm{~b}$ & $345 b$ & $9.0 \mathrm{a}$ & 5,984 & $1.9 \mathrm{a}$ & 35.3 & 44.6 & 1.22 \\
\hline Nias & 477.2 & $312.3 \mathrm{a}$ & $307 \mathrm{a}$ & $9.8 \mathrm{~b}$ & 6,462 & $2.2 b$ & 33.5 & 46.0 & 1.32 \\
\hline \multicolumn{10}{|c|}{ Populasi (tanaman $\mathrm{m}^{-2}$ ) } \\
\hline 133 & $350.2 \mathrm{a}$ & $253.7 \mathrm{a}$ & $247 \mathrm{a}$ & 9.1 & $4,908 \mathrm{a}$ & 2.1 & 34.7 & 46.7 & $0.89 \mathrm{a}$ \\
\hline 160 & $400.1 b$ & $327.6 b$ & $330 b$ & 9.6 & $6,296 b$ & 2.1 & 32.7 & 43.6 & $1.21 \mathrm{~b}$ \\
\hline 200 & $457.2 b$ & $335.1 \mathrm{~b}$ & $321 b$ & 9.4 & $5,896 \mathrm{ab}$ & 1.9 & 35.9 & 45.1 & $1.23 \mathrm{~b}$ \\
\hline 250 & $589.1 \mathrm{c}$ & $416.1 \mathrm{c}$ & $406 c$ & 9.5 & $7,792 \mathrm{c}$ & 2.0 & 34.3 & 45.8 & $1.74 \mathrm{c}$ \\
\hline \multicolumn{10}{|c|}{ Dosis pupuk (kg urea ha-1) } \\
\hline 200 & $416.1 \mathrm{a}$ & 314.4 & 306 & 8.9 & 5,701 & 2.1 & 34.5 & 47.0 & $1.16 \mathrm{a}$ \\
\hline 300 & $502.2 b$ & 332.7 & 332 & 9.5 & 6,582 & 2.1 & 34.4 & 45.3 & $1.32 b$ \\
\hline 400 & $496.5 b$ & 352.3 & 340 & 9.7 & 6,386 & 2.0 & 34.2 & 43.5 & $1.32 \mathrm{~b}$ \\
\hline Rata-rata & 471.6 & 333.1 & 326 & 9.4 & 6,223 & 2.0 & 34.4 & 45.3 & 1.27 \\
\hline
\end{tabular}

Keterangan: Angka yang diikuti huruf yang sama pada kolom yang sama untuk masing-masing perlakuan, tidak berbeda nyata. BBK = bobot brangkasan kering; Spi = spikelet (anak malai); IP = Indeks panen (hasil komersial dibagi hasil biologis atau Hasil/ BBK); B1000 = bobot 1,000 butir
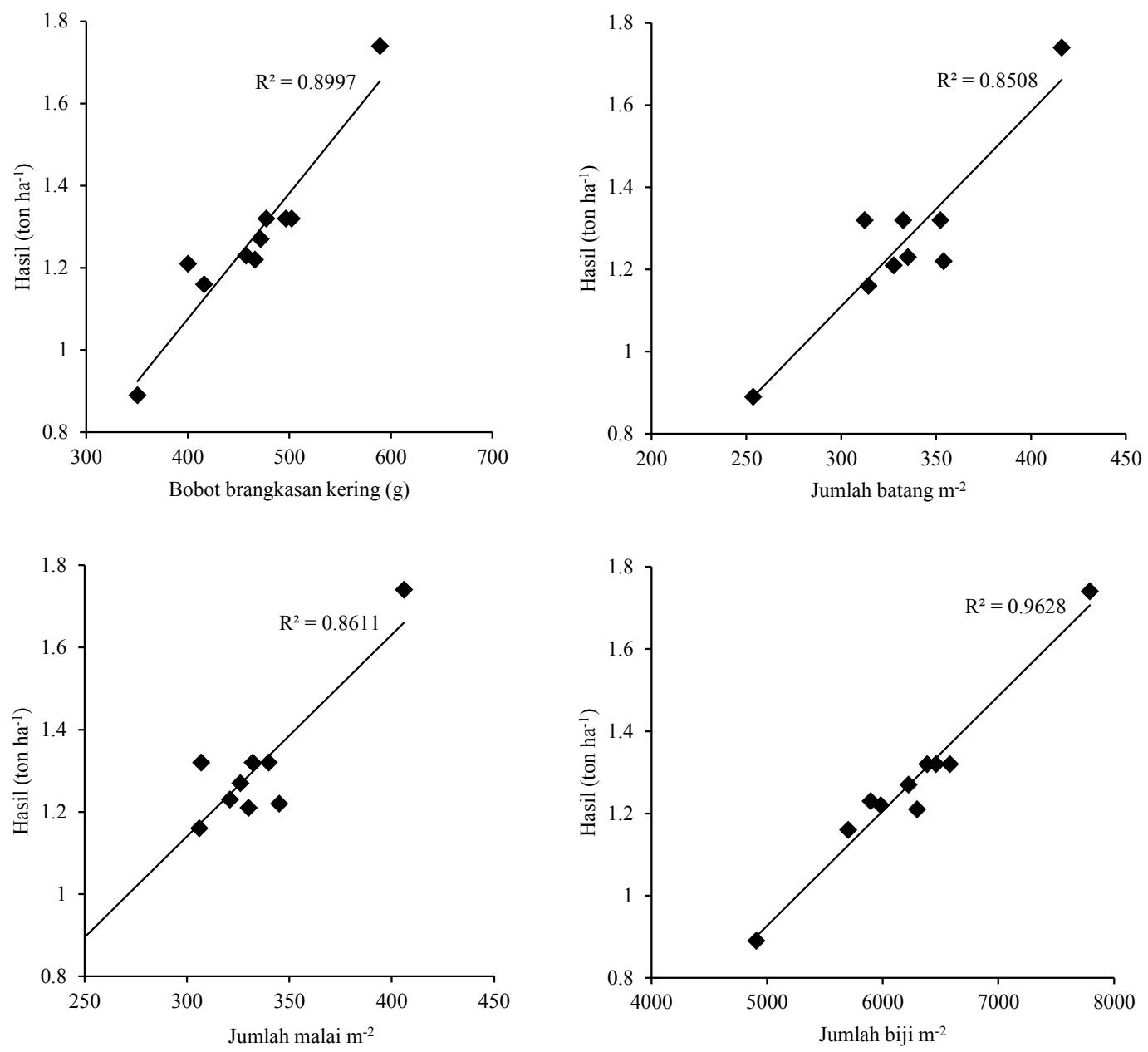

Gambar 3. Regresi antara hasil dan komponen-komponen hasil tanaman gandum 
Potensi panjang malai atau jumlah spikelet per malai pada percobaan ini relatif tetap, dan hasil lebih dipengaruhi oleh jumlah biji per satuan luas area. Peningkatan Jumlah biji $\mathrm{m}^{-2}$ ini disebabkan oleh peningkatan jumlah malai pada populasi tanaman yang lebih tinggi. Peningkatan Jumlah biji $\mathrm{m}^{-2}$ juga dapat disebabkan oleh lebih banyak keberhasilan pembuahan pada bunga meskipun potensi jumlah spikelet per malai tetap. Hal ini sejalan dengan usahausaha pemuliaan untuk adaptasi tanaman terhadap kondisi stress yang dilakukan dengan mempertahankan bunga yang terbentuk dari kerontokan (Alvaro et al., 2008).

\section{KESIMPULAN}

Varietas Nias dan Gladius memberikan hasil yang tidak berbeda nyata, berturut-turut 1.32 ton $\mathrm{ha}^{-1}$ dan 1.22 ton ha- ${ }^{-1}$. Populasi tanaman tertinggi (250 tanaman $\mathrm{m}^{-2}$ ) memberikan hasil tertinggi (1.74 ton $\left.\mathrm{ha}^{-1}\right)$, karena memberikan jumlah

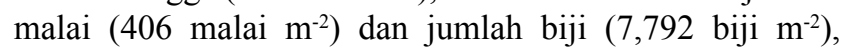
lebih banyak dari perlakuan populasi lainnya. Pemupukan gandum dapat dilakukan dengan dosis $300 \mathrm{~kg}$ urea ha ${ }^{-1}$ untuk mendapatkan hasil yang optimal (1.32 ton ha-1), lebih tinggi dari hasil dengan pemupukan $200 \mathrm{~kg} \mathrm{ha}^{-1}$ dan tidak berbeda dengan pemupukan $400 \mathrm{~kg}$ urea ha-1.

\section{DAFTAR PUSTAKA}

Ali, A., A. Ahmad, W.H. Syed, T. Khaliq, M. Asif, M. Aziz, M. Mubeen. 2011. Effects of nitrogen on growth and yield components of wheat. J. Sci. Internat. (Lahore) 23:331-332.

Alvaro, F., J. Isidro, D. Villegas, L.P. Garcia del Moral, C. Royo. 2008. Breeding effects on grain filling, biomass partitioning and remobilization in Mediterranean durum wheat. Agron. J. 100:361-370.

Araus, J.L., G.A. Slafer, C. Royo, M.D. Serret. 2008. Breeding for yield potential and stress adaptation in cereals. Critical Rev. Plant Sci. 27:377-412.

Baloch, M.S., T.H. Shah, M.A. Nadim, M.I. Khan, A.A. Khakwani. 2010. Effect of seeding density and planting time on growth and yield attributes of wheat. J. Plant Animal Sci. 20:239-242.

Faulkes, J.F., G.A. Slafer, W.J. Davies, P.M. Berry, R. Sylvester-Bradley, P. Martre, D.F. Calderini, S. Griffiths, M.P. Reynolds. 2011. Raising yield potential of wheat. III. Optimizing grain while maintaining lodging resistance. J. Exp. Bot. 62:469-486.

Febrianto, E.B., Y. Wahyu, D. Wirnas, 2015. Keragaan dan keragaman genetik karakter agronomi galur mutan putatif gandum generasi M5. J. Agron. Indonesia 43:52-58.
Food and Agriculture Organisation. 2012. FAO Statistics. http://www.fao.org. [15 Januari 2013].

Gusmayanti, E., S. Pertiwi, I. Handoko, I. Risdiyanto, T. Machida. 2006. Determining potential wheat growing areas in Indonesia by using the spatial compromise programming technique. Agric. Information Res. 15:373-379.

Handoko, I. 2007. Gandum 2000: Penelitian pengembangan gandum di Indonesia. SEAMEO-BIOTROP, Bogor, ID.

Laghari, G.M., F.C. Oad, S. Tunio, A.W. Gandahi, M.H. Siddiqui, A.W. Jagirani, S.M. Oad. 2010. Growth, yield and nutrient uptake of various wheat cultivars under different fertilizer regimes. Sarhad J. Agric. 26:489-497.

Mandic, V., V. Krnjaja, Z. Tomic, Z. Bijelic, A. Simic, D.R. Muslic, M. Gogic. 2015. Nitrogen fertilizer influence on wheat yield and use efficiency under different environmental conditions. Chilean J. Agric. Res. 75:92-97.

Nakano, H., S. Morita. 2009. Efect of seeding rate and nitrogen application rate on grain yield and protein content of the bread wheat cultivar 'Minaminokaori' in Southwestern Japan. Plant Prod. Sci. 12:109-115.

Parry, M.A.J., M. Reynolds, M.E. Salvucci, C. Raines, P.J. Andralojc, X-G. Zhu, G.D. Price, A.G. Condon, R.T. Furbank. 2011. Raising yield potential of wheat: II. Increasing photosynthetic capacity and efficiency. J. Exp. Bot. 62:453-467.

Putri, N.E., I. Chaniago, I. Suliansyah, 2013. Seleksi beberapa genotipe gandum berdasarkan komponen hasil di daerah curah hujan tinggi. J. Agroteknologi $4: 1-6$.

Reynolds, M., M.J. Foulkes, G.A. Slafer, P. Berry, M.A.J. Parry, J.W. Snape, W.J. Angus, 2009. Raising yield potential in wheat. J. Exp. Bot. 60:1899-1918.

Schillinger, W.F., S.B. Wuest. 2014. Wide row spacing for deep-furrow planting of winter wheat. Field Crops Res. 168:57-64.

Shearman, V.J., R. Sylvester-Bradley, R.K. Scott, M.J. Foulkes. 2005. Physiological processes associated with wheat yield progress in the UK. Crop Sci. 45:175-185. 
Spink, J.H., T. Semere, D.L. Spares, J.M. Whaley, M.J. Foulkes, R.W. Clare, R.K. Scott. 2000. Effect of sowing date on the optimum plant density of winter wheat. Ann. Appl. Biol. 137:179-188.

Talukder, A.S.M.H.M., G.K. McDonald, G.S. Gill, 2014. Effect of short-term heat stress prior to flowering and early grain set on the grain yield of wheat. Field Crops Res. 160:54-63.

Wahid, A., S. Gelani, M. Ashraf, M.R. Foolad. 2007. Heat tolerance in plants: An overview. Envi. Exp. Bot. 61:199-223.
Wardani, S., D. Wirnas, Y. Wahyu. 2015. Seleksi segregan gandum (Triticum aestivum L.) pada dataran tinggi. J. Agron. Indonesia 43:45-51.

World Meteorology Organisation (WMO). 2018. Lombok Indonesia Weather. http:/worldweather.wmo.int/en/ city.html?cityId=654. [10 Januari 2018].

Zadoks, J.C., C.T. Chang, C.F. Konzak, 1974. A decimal code for the growth stages of cereals. Weed Res. $14: 415-421$.

Zubaidi, A. 2015. Adaptation of wheat to a tropical environment. $\mathrm{PhD}$ Thesis. The University of Adelaide. Adelaide. 